Abstracta Iranica

Revue bibliographique pour le domaine irano-aryen

Volume 34-35-36 | 2017

Comptes rendus des publications de 2011-2013

\title{
Shahrokh Razmjou, Michael Roaf. Temples and Sacred Places in Persepolis
}

\section{Sébastien Gondet}

\section{(2) OpenEdition}

1 Journals

\section{Édition électronique}

URL : http://journals.openedition.org/abstractairanica/42117

DOI : 10.4000/abstractairanica.42117

ISSN : 1961-960X

Éditeur :

CNRS (UMR 7528 Mondes iraniens et indiens), Éditions de l'IFRI

Référence électronique

Sébastien Gondet, "Shahrokh Razmjou, Michael Roaf. Temples and Sacred Places in Persepolis », Abstracta Iranica [En ligne], Volume 34-35-36 | 2017, document 113, mis en ligne le 30 juillet 2017, consulté le 26 septembre 2020. URL : http://journals.openedition.org/abstractairanica/42117 ; DOI : https://doi.org/10.4000/abstractairanica.42117

Ce document a été généré automatiquement le 26 septembre 2020.

Tous droits réservés 


\title{
Shahrokh Razmjou, Michael Roaf. Temples and Sacred Places in Persepolis
}

\author{
Sébastien Gondet
}

\section{RÉFÉRENCE}

Shahrokh Razmjou, Michael Roaf. « Temples and Sacred Places in Persepolis », in: K. Kaniuth, A. Löhnert, J. L. Miller, A. Otto, M. Roaf and W. Sallaberger, eds., Tempel im Alten Orient. 7. Internationales Colloquium der Deutschen Orient-Gesellschaft, 11.-13. Oktober 2009, München. Wiesbaden, Harrassowitz Verlag, 2013, p. 407-425. (Colloquien der Deutschen Orient-Gesellschaft Band 7)

1 En conclusion de cet article les AA. estiment que l'importance de Persépolis comme site religieux a été sous-estimée. Cette affirmation est assez étonnante puisque cette contribution s'ajoute à la longue liste d'articles qui confèrent à Persépolis, toujours limitée à sa seule terrasse monumentale et aux quelques bâtiments avoisinants, un rôle essentiellement symbolique et rituel. Aucune des données présentées ici n'apporte un éclairage nouveau et convaincant sur l'identification de vestiges archéologiques de lieux de culte d'époque achéménide en Perse. On est à nouveau obligé de constater qu'il existe un gouffre béant entre la richesse et la variété des pratiques religieuses en Perse au cours de la période achéménide, que laissent deviner les archives de Persépolis, et la pauvreté de la documentation archéologique. 


\section{AUTEURS}

\section{SÉBASTIEN GONDET}

UMR 5133 CNRS-Université de Lyon 